\title{
Mining Beneficiation Obligation in Indonesia: Are We There Yet?
}

\author{
Genio Ladyan Finasisca ${ }^{1 *}$, Tri Hayati ${ }^{1}$
}

\author{
${ }^{1}$ Faculty of Law, Universitas Indonesia, Depok, Indonesia \\ *Corresponding author. Email: jennyfinasisca@gmail.com
}

\begin{abstract}
New Indonesian Law regarding Mineral and Coal Mining was enacted in 2009 with a high expectation of developing Indonesian mining sector to the next stage in particular and also to encourage economic growth. This law imposed certain new provision to the mining sector regarding downstream mining policy, which is the obligation to process and refined extracted mineral in Indonesia and prohibition to export raw unprocessed mineral. Hence, the stipulation of this policy can be regarded as a reformation form of mineral mining in Indonesia. Since 2009, there has been certain regulation applied as derivation of Indonesian Law number 4/2009 regarding the mineral processing and purification obligation, in which will elaborate and analyze in this research. This research uses doctrinal research method supported by non-doctrinal research, so that there is a complete picture about the Indonesia's mining downstream policy regarding the mineral processing and purification obligation. This research uses method of regulatory approach and practice approach of mining downstream system in Indonesia. The result of this study indicates that this regulation is issued to objectify people's wealth maximization in Indonesia. This regulation also issued as a form of state ownership right over natural resources. However, a decade after this obligation established as law, the realization of mineral beneficiation obligation in Indonesia has not implemented effectively.

Keywords: mineral, mining downstream policy, processing and purification obligation, welfare state
\end{abstract}

\section{INTRODUCTION}

Indonesia is a country with a remarkable natural profile consisting of 17.500 islands and contains $15 \%$ of the world's active mountains, Indonesia has a high number of natural resource commodities [1]. Based on Performance Report of the Ministry of Energy and Mineral Resources (ESDM) in 2016, Indonesia's total mineral resources consist of 815,46 tons of bauxite, 359.45 tons of ore; 3820.16 tons of primary gold metal; and 3,172. 16 tons of copper [2]. This number has placed Indonesia as one of the highest ranking countries in terms of production and exporters of mining materials in the world. With the high number of mineral resources commodities, Indonesia's mining sector is the largest contributor to the state's revenue. Recent data show that the ESDM sector non-tax state revenue (PNBP) accounts for almost half of the national PNBP target of 2017. The value reaches IDR 129.07 trillion or $49.6 \%$ of national PNBP by 2017 . While until the end of January 2018, the ESDM sector still plays a dominant role for national economic growth, contrary to the fact that the number of Indonesia's mineral resources commodities is very high, the growth of the manufacturing industry and the performance of Indonesia's manufacturing sector is still weak [3]. In short, despite all the natural resources wealth Indonesia has to produce another product that has added value compared to the raw resources, Indonesia manufacturing sector is still not well grown until this recent year. Contrary to the fact that the number of

\begin{abstract}
Indonesia's mineral resources commodities is very high, the growth of the manufacturing industry and the performance of Indonesia's manufacturing sector is still weak. The mineral downstream policy, which began to be established since 2009, has basically been expected to increase the growth of Indonesia's manufacturing industry.

There are few research questions that are going to be answered in this paper. First: what is Indonesia's mining downstream policy in regarding of the mineral processing and purification obligation? and second, how is the realization of Indonesian ownership right regarding the mineral processing and refining obligation in Indonesian Mining Law?. These questions are answered with research results using doctrinal research method supported by nondoctrinal research to refine the description of the application of mineralized downstream in Indonesia, so there will be a complete picture about the current mining downstream regulation in Indonesia. This research uses method of regulatory approach and practice approach of mining downstream system in Indonesia.
\end{abstract}

\section{DISCUSSION}

\subsection{Indonesia's Mining Downstream Policy}

Indonesian Law number 4 of 2009 (Indonesian Mining Law) is a new regime of law that brings a lot of polemic in Indonesian mining sector. This new law set a new obligation and restriction, which include increment of mining tax and royalty payments, divestment rules, the high level over export tariffs of unprocessed minerals and mineral 
beneficiation obligation which caused the export ban for raw minerals [3].

Mineral beneficiation obligation is an activity related to mineral downstream sector. This obligation is held on one of the main stages in mineral business activities. The main activities of mineral business consist of mining activities, smelting, and finally refining [4]. Of the three main activities, mining activity is included in the upstream sector, while smelting and refining are included in the downstream sector. Activities in the downstream sector are further known as hilirisasi (downstream/mining) [5].

As a new policy set forth in Indonesian mining law, mineral downstream is considered a form of revolution in the mining industry which due to changing the pattern of Indonesian downstream mining activities [6]. Mineral processing and refining activity itself were already recognized under the previous mining law, Indonesian Mining Law number 1 of 1960 (Indonesian Mining Law 1960) and Indonesian Mining Law number 11 of 1967 (Indonesian Mining Law 1967). Both of this law has been regulated this activity, and defined them as an activity to improve the quality of mining materials obtained by mining concessions in the conduct of its mining operations in Indonesia [7]. In the regime of the Indonesian Mining Law 1967, it has also been regulated further on the Mining Processing and Refinery Process. The Mining Authority of processing and refining is the authority granted to the holder of mining authority for work to enhance the quality of minerals and to utilize and obtain the elements contained in the minerals [8]. Even in the contract of work agreed upon in the regime of the Mining Law of 1967, the provisions of downstream have existed. According to Juwana, downstream activities have never been realized. The unavailability of this activity is most likely caused by the low bargaining position of the Indonesian government. At this time, the government needs contractors with technology, experts and funds [9].

Indonesian Mining Law mandated the holders of Mining Business License (IUP) and Special Mining Business License (IUPK) to do increasement mineral added value throughout processing and refining in term of mineral and coal utilization under article 102 and 103 of Indonesian Law number 4 of 2009. For the holders of Work Contract (known as Kontrak Karya, article 170 firmly stated that this obligation has to be fulfilled no later than January 12, 2014 of Indonesian Law number 4 of 2009. This mandate is followed by regulations related to the control of mineral ore exports. Clearly, the current law has been strongly stated this obligation even more than the previous law.

The enactment of these regulations begins with a consistent spirit to require the implementation of mineral downstream as well as the revival of the new revolution in the mining industry. This is shown by the issuance of regulations in line with the policies issued by the government related to the export ban of raw minerals (without exception) in 2012 through Government Regulations number 23 of 2010 and Ministry of Energy and Resources Regulation number 7 of 2012 [10]. Government Regulations number 23 of 2010 regarding the implementation of mineral and coal mining business activities stated on article 84 paragraph (1) that the owner of IUP Production Operation and IUPK Production Operation must prioritize Indonesian mineral and/or coal needs. This regulation also restated the obligation of IUP operation production and IUPK production operation to process and refine the mineral as an adding value process by them self or by cooperating with another company, another IUP owner or IUPK owner [11].

Following the enactment of Government Regulations number 23 of 2010, Indonesian government also published another regulation regarding the mineral adding value process under Ministry of Energy and Resources Regulation number 7 of 2012. This regulation ruled the processing and refining obligation to be held for the mineral commodity and its side products. This regulation also specified the technical procedure of cooperation system between the holders of IUP production operation to do the mineral value adding process. The cooperation mentioned above is included to ore/concentrate selling, processing and refining process, and also regarding the development of facilities and infrastructure [12].

However, post-2012, a series of policies that subsequently issued by the government actually looks inconsistent by continuing to provide additional time. This inconsistency shows in Government Regulation number 1 of 2014 which permitted the export of concentrate until January 2017 This relaxation continue until January 12, 2002 through Government Relation number 1 of 2017. The provision under the previously mentioned government and ministry regulation shows inconsistency throughout the main regulation itself which clearly stated the deadline mandate to do mineral processing and refining process domestically [13].

In Indonesia, the regulatory regime governing mining investment can be characterized as a set of rules and policies promulgated by legislative and executive power in order to regulate the relationship between the state, investors and locals regarding mining investment. This function is an integral part of governance infrastructure consisting of political, institutional and legal environment of particular state. The quality of the regulatory regime governing mining investment significantly influences the investment decisions of investors. Thus, the uncertainty of law shown on this topic is becoming a big thread toward Indonesian investment climate [14].

\subsection{Mineral Processing and Purification Obligation and The Ownership Right of The State}

Mineral processing and purification obligation is Indonesian government way to enhance the utilization of natural resources commodity. This phenomenon is not only happened in Indonesia. In fact, it almost happened in every resource-rich country whom trying to get the utmost economic benefit through natural resources utilization. This phenomenon recognized as a form of resource nationalism using local content policy [15].

In the broadest sense, resource nationalism refers to state intervention in natural resource industries in order to exert more control over the terms of private investment [16]. The way of government interventions targets private capital, and usually foreign capital, in particular, and can range in form 
from the nationalization of foreign assets, restrictions on foreign investment, to less contentious initiatives that increase taxes and royalty payments [17]. The logic is twofold: first, boom times provide governments of resource-rich countries greater leverage in their negotiations with foreign investors and more influence over international commodity markets [18]; second, there is more money to be made during a boom, which motivates (often corrupt) state officials and politically connected business groups to seek greater access to resource rents via state intervention [19].

Resources nationalism encompasses a broad range of political and economic actions taken by government to regulate natural resources utilization. In this term, the action is held by obligate every mining sector stakeholders in Indonesia to do mineral processing and refining domestically. In Indonesia's case regarding mineral beneficiation obligation, government interventions happen to gain full control of mining commodities as a way to maximize the utilization of natural resources to embodied wealth maximization. Government is trying to find a way to sustain mining sector income, by not only from the natural resources mining sector but also to envision natural resources mining industries.

In Indonesia, philosophically, the concept of mineral processing and purification under mining downstream sector is closely related to Indonesia constitutional idealism that emphasize the utility of natural resources for wealth maximization. Theoretically, this downstream activity can increase the greater value added for the mining sector, both from non-taxes income (PNBP) and taxes. Thus, the mineral downstream can provide greater benefits for the people. If the government does not implement a mineral downstream policy, Indonesia will lose potential revenues projected to potentially gain a minimum of US $\$ 10.8$ billion and will lead to the development of the mining and manufacturing industry. Mineral downstream also needs to be applied to reduce Indonesia's dependence on primary commodity exports as is the case in Indonesia today [20]. According to Indonesian Ministry of Trade, the efforts of mineral mining downstream have goals and objectives [21]:

a. prevention of excessive exploitation in the mining sector which may damage the environment;

b. development of downstream industries in order to create a highly competitive mining processed product;

c. supporting the availability of domestic mine raw materials;

d. increased investment through smelter development and processing industries and increased employment;

e. traceability of mining products in order to enhance the supervision of the legality of mining management and royalty payments through verification policies.

The downstream setting of mineral mining is also considered beneficial because it has the following benefits [22]:

a. guaranteed business certainty in accordance with the operation period;

b. encouraging the acceleration of smelter development;

c. increase of sale price of processed and / or refined mineral products;

d. increase employment from processing and refining;

e. increase the role of state / national in mining concession.
Based on data mentioned above, mineral beneficiation obligation implementation has its own urge and necessity to be implemented well. The urge and necessity basically related to the fact of this policy impact toward countries GDP. This policy also can be seen as a form of way toward realization of wealth maximization.

Under article 33 (3) of Indonesian constitution, wealth maximization is the objective of natural resources utilization. This article stated that "earth, water and natural resources contained are owned by the state and used for the biggest prosperity of people". Indonesian Constitutional Court further interpret this article as an economic ideology of Indonesia. Court furtherly explained that the utilization of natural resources in Indonesia is based on the ownership right given to the state and must be used upon the realization of wealth maximization.

The ownership right by the state in the article mentioned is regarding to the management of nature resources and important production sector that affect the livelihood of many people. The ownership right in this term is different from ownership right during Dutch Colonial Era. The ownership right in this term is regarding to the right of the state to rule and managed, in which can be concluded as the management right of Indonesia's nature resources.

There has been a lot of dispute regarding the definition of the ownership right within the article mentioned above. Indonesian Constitutional Court in number 002/PUUI/2003 defined the "owned by the state" phrase in the article 33 (4) of Indonesian Constitution in 4 definitions. First, is the right of the state to make a policy. Second, is the right to do the management action. Third is to do the ruling. Fourth is to do the management and supervising, all, solely in regard to the prosperity of the people. As the owner the state natural resources, the government also has to comply the economic program with the economic democracy basis with the principle of togetherness, efficiently justified, sustainability, environmental-basis, autonomy, also by maintaining the balance of progress and national economic unity.

The management and utilization of natural resources in Indonesia is oriented to the people's prosperity, which also based on article 1 paragraph (2) of Indonesia Constitution that stated "the highest sovereignty is in the hand of people". Also, as has been confirmed by the Constitutional Court in the decision number 10/PUU-XII/2014 that the processing and refining obligations in the country in accordance with Article 33 of the 1945 Constitution because this obligation directly or indirectly provide the greatest benefit to the welfare of the people [23].

Constitutional Court defined the "biggest prosperity of the people" phrase in 4 (four) criteria. First one is the maximization of the natural resources for the people. In this term, constitutional court ordered that the higher the expediency of the natural resources will maximize the utilization of the natural resources for the prosperity of the people. The second one is regarding to the equality of natural resources utilization. All of Indonesian citizen has to be benefited by the utilization of the natural resources. The third one is regarding to how far the people can participate to determine the utilization of the natural resources. And the last one is regarding to the reverence of the people hereditary rights to utilize the natural resources. 


\subsection{Mineral Processing and Purification Obligation Progress in Indonesia}

As a revolutionary policy that has changed Indonesian mining sector pattern, mineral value-added obligation at least has 2 (two) legal consequences for mining sector stakeholders, the first consequence is regarding the export ban toward raw mineral exports. Since 2009, this policy has made up several "Drama" in Indonesia's mining sector business. Indonesia government has been accused of being inconsistent to implement their own regulation. The obligation that initially implemented at 2009, has been pushed to 2014, and lastly to 2017. There has been 10 years of delayed toward the implementation of this policy that shows Indonesia's government itself is inconsistent and not essentially ready to implement article 102 and 103 of Law no.4/2009. This issue is not inseparable from Indonesian government' weaknesses in terms of uncertainty in supervision, unclear process of renegotiation of mining contracts, as well as double standards in granting mineral export licenses applied by the Indonesian government [24]. Researches also shown that "Drama" regarding raw mineral export ban and export relaxation also affecting Indonesian mineral production export volume. Furthermore, this problem also affecting Indonesian GDP as there is a derivation in mining sector contribution to Indonesian GDP, as shown in Figure 1 and Table I [25].

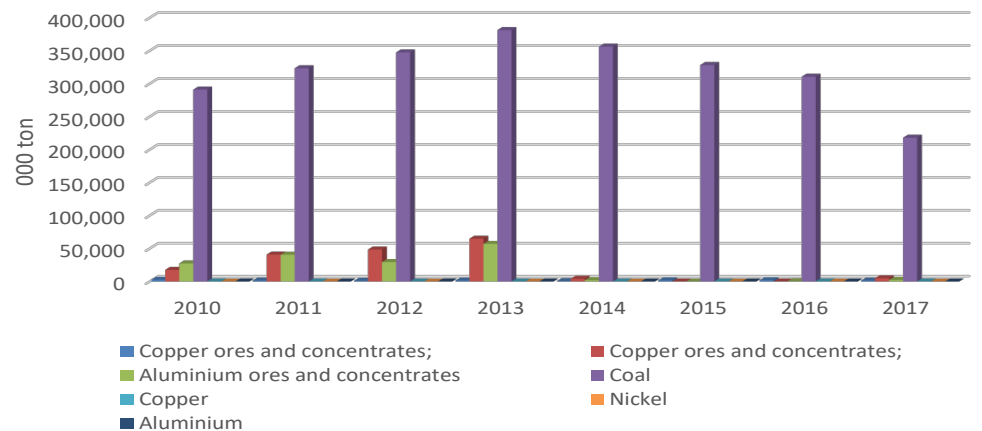

Figure 1 Indonesian mining commodity export 2010-2017

Previous data above shows that there has been some derivation toward Indonesia's income from mining sector, that is not inseparable from the fact that Indonesia has applied mineral export ban nor relaxation.

Mineral beneficiation regulation also delivers another consequence for stakeholders to build their own smelter. Although under Indonesian Government Regulation number 1 of 2017 gives facilitation for stakeholders by giving permission for stakeholders to co-work and use a smelter together, but stakeholders still have pressure to build a smelter inside Indonesian territory. Problem mentioned above arise regarding Indonesian wide territory that is detached by sea into thousands of islands and uneven distribution of natural resources in Indonesia's land.

Based on the Strategic Plan of the Ministry of Energy and Mineral Resources for 2015-2019, the government plans to realize the construction of processing facilities and refineries in the country of 30 (thirty) smelters. The construction of 30 (thirty) smelters is expected to increase mineral processing capacity to 59.5 million tons, which includes nickel ore processing capacity of 19 million tons, iron ore by 17 million tons, bauxite ore by 20 million tons, manganese ore by 0,6 million tons and copper concentrate of 2.9 million tons. The smelter construction facility that will be built is also directed to several regions, namely West Kalimantan for the construction of fine processing facilities, and Sulawesi Landmark, North Sulawesi and North Maluku for the construction of nickel processing facilities. Meanwhile, iron and copper ore processing facilities are directed to locations that already have infrastructure and are close to energy / electricity sources. This is due to the characteristics of iron ore and copper ore resources which are scattered with small reserves, so that it is considered to be more efficient if the processing facilities are concentrated in one particular area that has adequate supporting infrastructure and energy sources [26].

In realization, existing smelter in Indonesia until 2019 is reaching 27 smelters. But based on Indonesian Ministry of Energy and Mineral Resources' statement on a direct interview on 2019, not all of this smelter is active. Several smelters are still on idle and not on their operation mode. The amount of infestation realization also does not meet the exceeded expectation and plan as seen on Table 1.

Table 1 Smelter Development Progress in Indonesia

\begin{tabular}{|l|l|l|l|l|l|l|}
\hline No & COMMODITIES & EXISTING & PLAN & $\begin{array}{l}\text { AMOUNT } \\
\text { OF } \\
\text { SMELTER }\end{array}$ & $\begin{array}{l}\text { INVESTATION } \\
\text { PLAN (000USD) }\end{array}$ & $\begin{array}{l}\text { INVESTATION } \\
\text { REALIZATION } \\
\text { (000USD) }\end{array}$ \\
\hline 1. & Copper & 2 & 3 & 5 & 4.392 .208 & $246.611,88$ \\
\hline 2. & Nickel & 17 & 16 & 33 & 5.380 .902 & $1.823 .443,35$ \\
\hline 3. & Bauxite & 2 & 5 & 7 & 4.978 .402 & $1.776 .076,62$ \\
\hline 4. & Iron & 4 & 2 & 6 & 60.684 & 36.582 \\
\hline 5. & Manganese & 2 & 0 & 2 & 2.485 & 2.485 \\
\hline 6. & Zinc & 0 & 4 & 4 & 35.911 & 12.865 \\
\hline \multicolumn{2}{|l|}{ Total } & $\mathbf{2 7}$ & $\mathbf{3 0}$ & $\mathbf{5 7}$ & $\mathbf{1 4 . 8 5 0 . 5 9 3}$ & $\mathbf{3 . 8 9 8 . 0 6 4}$ \\
\hline
\end{tabular}


[5] Armando Mahler and Nurhaidi Sabirin, Dari Grasberg Sampai Amamapare. Jakarta : Gramedia Pustaka Utama, 2008.

[6] Abrar Saleng (2015, January 28), UU Minerba dan Revolusi Industri Pertambangan [news article] available : http://beta.investor.id/opinion/uu-minerba-danrevolusi-industri-pertambangan

[7] Indonesia, Undang-Undang nomor 11 tahun 1960, article (f).

[8] Mukmin Zakie, "Kaitan Kuasa Pertambangan dengan Hak-Hak Atas Tanah dalam Undang-Undang Pokok Agraria", Jurnal Hukum Vol. 7, no.13, hal. 65, April 2000.

[9] Indonesia, Putusan Mahkamah Konstitusi Nomor 10/PUU-XII/2014.

[10] Farida Husna and Ben Otto, "Indonesia Gives Details on its Mineral Export Ban", The Wall Street Journal, January 13, 2014,

https://www.wsj.com/articles/indonesia-gives-detailson-its-mineral-export-ban-1389618270)

[11] Indonesia, Peraturan Pemerintah nomor 23 tahun 2010 .

[12] Indonesia, Peraturan Menteri ESDM nomor 7 tahun 2012.

[13] Indonesia, Peraturan Pemerintah nomor 1 tahun 2017.

[14] Bernadetta Devi, "Mining and Development in Indonesia: An Overview of the Regulatory Framework and Policies", March 2013, http://im4dc.org/wpcontent/uploads/2013/09/Mining-and- Development-inIndonesia.pdf

[15] USGS, "Resource Nationalism in Indonesia Effects of 2014 Mineral

ExportBanhttps://pubs.usgs.gov/fs/2016/3072/fs201630 72.pdf;

[16] Eve Waburton, "Resource Nationalism in PostBoom Indonesia : The New Nornal”, April 2007, Lowy Institute, https://www.thinkasia.org/bitstream/handle/11540/7088/Warburton_Indo nesia_FINAL\%20WEB.pdf?sequence $=1$

[17] Ernest J Wilson, "World Politics and International Energy Markets.” International Organization 41 (1), 1987, p. 125-149.

[18] David Humpreys, "New Mercantilism: A Perspective on How Politics is Shaping World Metal Supply”, Resources Policy 38 (3), 2011, p. 341-349. 
[19] Solomon, Michael. "The Rise of Resource Nationalism: A Resurgence of State Control in an Era of Free Markets or the Legitimate Search for a New Equilibrium?", 2012, The Southern African Institute of Mining and Metallurgy. www.polity.org.za/article/therise-of-resource-nationalism-a-resurgence-of-statecontrol-in-an-era-of-free-markets-or-the-legitimatesearch-for-a-new-equilibrium-july-2012-2012-07-177.

[20] Pihri Buhaerah, "Urgensi Hilirisasi Mineral Pertambangan”, 2018, Kontan

https://m.kontan.co.id/news_analisis/urgensi-hilirisasimineral-pertambangan? page $=2$,

[21] Indonesia Ministry of Trade, Analisis Dampak Kebijakan Pelarangan Ekspor Raw Material Tambang dan Mineral, (Jakarta : Badan Pengkajian

Pengembangan Kebijakan Perdagangan, 2013)

[22] Indonesia Ministry of Trade, Analisis Dampak Kebijakan Pelarangan Ekspor Raw Material Tambang dan Mineral, (Jakarta : Badan Pengkajian Pengembangan Kebijakan Perdagangan, 2013)

[23] Indonesia, Putusan Mahkamah Konstitusi Nomor 10/PUU-XII/2014.

[24] Indonesia, Putusan Mahkamah Konstitusi Nomor 10/PUU-XII/2014.

[25] Ahmad Redi, “Teguran Presiden Tidak Mengubah Aturan Minerba” 30 July 2017, Kontan, http://amp.kontan.co.id/news/teguran-presiden-tidakmengubah-aturan-minerba

[26] Rencana Strategis KESDM 2015-2019, accessed from

https://www.esdm.go.id/assets/media/content/Renstra KESDM.pdf accessed 13 October 2019.

[27] Uka Wikasyah “efektifitas dan kebijakan hilirisasi minerba dan transparansi tata kelola", presented at lembaga penyelidikan ekonomi dan masyarakat FEB UI, Jakarta, 2019. 